$10-2008$

\title{
Determinants of Success in National Programs to Eliminate Lymphatic Filariasis: a Perspective Identifying Essential Elements and Research Needs
}

Dominique Kyelem

The Task Force for Global Health, Decatur, Georgia

Gautam Biswas

Moses J. Bockarie

Case Western Reserve University School of Medicine

Mark Bradley

Global Community Partnerships

Maged El-Setouhy

See next page for additional authors

Follow this and additional works at: https://scholarworks.smith.edu/bio_facpubs

Part of the Biology Commons

\section{Recommended Citation}

Kyelem, Dominique; Biswas, Gautam; Bockarie, Moses J.; Bradley, Mark; El-Setouhy, Maged; Fischer, Peter U.; Henderson, Ralph H.; Kazura, James W.; Lammie, Patrick J.; Njenga, Sammy M.; Ottesen, Eric A.; Ramaiah, Kapa; Richardson, Frank O.; Weil, Gary J.; and Williams, Steven A., "Determinants of Success in National Programs to Eliminate Lymphatic Filariasis: a Perspective Identifying Essential Elements and Research Needs" (2008). Biological Sciences: Faculty Publications, Smith College, Northampton, MA. https://scholarworks.smith.edu/bio_facpubs/17

This Article has been accepted for inclusion in Biological Sciences: Faculty Publications by an authorized administrator of Smith ScholarWorks. For more information, please contact scholarworks@smith.edu 


\section{Authors}

Dominique Kyelem, Gautam Biswas, Moses J. Bockarie, Mark Bradley, Maged El-Setouhy, Peter U. Fischer, Ralph H. Henderson, James W. Kazura, Patrick J. Lammie, Sammy M. Njenga, Eric A. Ottesen, Kapa Ramaiah, Frank O. Richardson, Gary J. Weil, and Steven A. Williams 


\title{
Determinants of Success in National Programs to Eliminate Lymphatic Filariasis: A Perspective Identifying Essential Elements and Research Needs
}

\author{
Dominique Kyelem,* Gautam Biswas, Moses J. Bockarie, Mark H. Bradley, Maged El-Setouhy, Peter U. Fischer, \\ Ralph H. Henderson, James W. Kazura, Patrick J. Lammie, Sammy M. Njenga, Eric A. Ottesen,* Kapa D. Ramaiah, \\ Frank O. Richards, Gary J. Weil, and Steven A. Williams \\ Lymphatic Filariasis Support Center, Task Force for Child Survival and Development, Decatur, Georgia; Department of Control of \\ Neglected Tropical Diseases, World Health Organization, Geneva, Switzerland; Lymphatic Filariasis Support Centre, Liverpool \\ School of Tropical Medicine, Liverpool, United Kingdom; Global Community Partnerships, GlaxoSmithKline, Brentford, United \\ Kingdom; Department of Public Health, Ain Shams University, Cairo, Egypt; School of Medicine, Washington University, St. Louis, \\ Missouri; Center for Global Health \& Diseases, Case Western Reserve University, Cleveland, Ohio; Division of Parasitic Diseases, \\ Centers for Disease Control and Prevention, Atlanta, Georgia; Kenya Medical Research Institute, Nairobi, Kenya; Vector Control \\ Research Centre, Indian Council of Medical Research, Pondicherry, India; Carter Center, Atlanta, Georgia; Clark Science Center,
} Smith College, Northampton, Massachusetts

\begin{abstract}
The Global Programme to Eliminate Lymphatic Filariasis (GPELF) was launched in 2000. To understand why some national programs have been more successful than others, a panel of individuals with expertise in LF elimination efforts met to assess available data from programs in 8 countries. The goal was to identify: 1) the factors determining success for national LF elimination programs (defined as the rapid, sustained reduction in microfilaremia/ antigenemia after repeated mass drug administration [MDA]);2) the priorities for operational research to enhance LF elimination efforts.

Of more than 40 factors identified, the most prominent were 1) initial level of LF endemicity; 2) effectiveness of vector mosquitoes; 3) MDA drug regimen; 4) population compliance.

Research important for facilitating program success was identified as either biologic (i.e., [1] quantifying differences in vectorial capacity; [2] identifying seasonal variations affecting LF transmission) or programmatic (i.e., [1] identifying quantitative thresholds, especially the population compliance levels necessary for success, and the antigenemia or microfilaremia prevalence at which MDA programs can stop with minimal risk of resumption of transmission; [2] defining optimal drug distribution strategies and timing; [3] identifying those individuals who are "persistently noncompliant" during MDAs, the reasons for this non-compliance and approaches to overcoming it).

While addressing these challenges is important, many key determinants of program success are already clearly understood; operationalizing these as soon as possible will greatly increase the potential for national program success.
\end{abstract}

\section{BACKGROUND AND APPROACH}

Since the official launch of the Global Program to Eliminate Lymphatic Filariasis (GPELF) in $2000,{ }^{1}$ almost 2 billion doses of once-yearly anti-filarial drug treatment have been administered to over 570 million people through national programs in 48 of the world's 83 endemic countries. ${ }^{2}$ It is not surprising that some of these programs have been more successful than others. Now that a number of the early programs are approaching the point at which they can contemplate stopping the MDA component of their programs, it is possible to look retrospectively to identify factors that have influenced their outcomes. Such evaluation provides an opportunity to guide ongoing and still-to-be-initiated national programs toward adopting more successful strategies, and it identifies key biologic, epidemiologic, and programmatic uncertainties that might be addressed through targeted research.

Collection of detailed analytical data has not been a standard component of most national MDA programs, so the richest source of information for identifying potential determinants that affect program outcome lies with those programs working closely with research teams from either government

\footnotetext{
* Address correspondence to Dominique Kyelem or Eric A. Ottesen, Lymphatic Filariasis Support Center, Task Force for Child Survival and Development, Decatur, Georgia. E-mails: dkyelem@taskforce .org and eottesen@taskforce.org
}

research institutions or academia. In some instances these collaborating research teams have directly tracked the progress of the national programs, and in others they have made detailed observations at study sites where treatment activities were carried out in parallel to those of the national program.

To capture the experiences of programs that have been closely monitored (epidemiologically, entomologically, and through laboratory studies) in different parts of the world, investigators from programs in 8 countries (Table 1) provided information identifying successes and failures within each program and the likely reasons for these outcomes. Although program "success" can have many dimensions, here the principal measure of success was the decrease in microfilaremia prevalence, a sine qua non of LF elimination. The specific factors evaluated in relation to this marker of success-either having a positive influence (i.e., leading toward greater impact or shorter duration of MDA activities) or a negative influence (i.e., leading toward lesser impact or longer duration of MDA activities) - are detailed in Table 2. Some of these factors represent determinants that will have an effect on program outcome regardless of how effectively the program itself is carried out (Table 2a), whereas others relate principally to the operational effectiveness of the programs themselves (Table 2b). The conclusions in Table 2 largely reflect the considered assessment and consensus of the investigators themselves after analysis and discussion of, in most instances, published data describing the impact of MDA on 
TABLE 1

National LF elimination activities assessed in this perspective

\begin{tabular}{llc}
\hline \multicolumn{1}{c}{ Program country } & \multicolumn{1}{c}{ LF parasite } & No. of MDAs \\
\hline Burkina Faso & Wuchereria bancrofti & 5 \\
Egypt & W. bancrofti & 5 \\
Haiti & W. bancrofti & 5 \\
India & W. bancrofti & 9 \\
Indonesia & Brugia timori & 6 \\
Kenya & W. bancrofti & 2 \\
Nigeria & W. bancrofti & 6 \\
Papua New Guinea & W. bancrofti & 7 \\
\hline
\end{tabular}

microfilaria prevalence and transmission ${ }^{3-19}$ and, in other cases, less formal reports of LF elimination program activity. ${ }^{20-22}$

\section{DETERMINANTS AFFECTING PROGRAM OUTCOME}

More than 40 different determinants affecting program outcome were identified and described as leading to either greater or lesser likelihood of success (defined as the rapid and sustained fall in the prevalence of microfilaremia) for the MDA-based LF elimination programs (Table 2).

Among the most prominent factors to affect program outcome were: 1) the initial level of LF endemicity (i.e., prevalence and density of microfilaremia);2) the competence and vectorial capacity of the local vector; 3 ) the drug regimen used for the MDAs; and 4) both population coverage* and population compliance. $\dagger$

Some of the determinants noted in Table 2 are not easily changed-particularly those that are biologic/epidemiologic in nature or those that reflect the underlying socioeconomic and political environments of the endemic areas. Despite their being relatively unchangeable, however, programs do need to recognize their influence when implementation strategies are being developed.

Other determinants are more readily modifiable-such as compliance within the endemic communities and coverage of the target population. These, in turn, are heavily dependent on 1) the operational effectiveness of the programs (especially social mobilization, supervision and monitoring), 2) the adequacy of resources (both funding and human), and 3) the political commitment to support the program.

\section{IDENTIFYING RESEARCHABLE ISSUES}

Although many of the factors identified in Table 2 are not amenable to research or have been so well documented

\footnotetext{
* Defined by the proportion of the population targeted by the program that was provided with the appropriate drugs.
}

$\dagger$ Defined by the proportion of eligible individuals actually ingesting the drugs provided to them.

TABLE 2a

Determinants influencing outcome of LF elimination programs

\begin{tabular}{|c|c|c|c|c|}
\hline Factor & Positive influence* & Negative influence $\dagger$ & $\begin{array}{l}\text { Readily } \\
\text { changeable }\end{array}$ & $\begin{array}{l}\text { Important/ } \\
\text { researchable }\end{array}$ \\
\hline \multicolumn{5}{|l|}{ Biologic/epidemiologic/therapeutic } \\
\hline Endemicity (prevalence/density) & Low & High & No & $\checkmark$ \\
\hline Human population & Small & Large & No & \\
\hline Endemic areas & $\begin{array}{l}\text { 1) Easily accessed } \\
\text { 2) Rural }\end{array}$ & $\begin{array}{l}\text { 1) Remote } \\
\text { 2) Urban }\end{array}$ & No & \\
\hline Vector density & Low & high & Yes & $\checkmark$ \\
\hline Vector species & $\begin{array}{l}\text { Anopheles (? some better } \\
\text { than others) }\end{array}$ & Aedes or Culex & No & $\checkmark$ \\
\hline Transmission & Seasonal & Year-round & No & $\checkmark$ \\
\hline Parasite species & Anthropophilic Brugia & W. bancrofti & No & \\
\hline MDA treatment regimen & $\begin{array}{l}\text { DEC (diethylcarbamazine) + } \\
\text { albendazole }\end{array}$ & Ivermectin + albendazole & $+/-$ & $\checkmark$ \\
\hline Ivermectin dosage in regimen & $400 \mathrm{mcg} / \mathrm{kg}$ & $150-200 \mathrm{mcg} / \mathrm{kg}$ & Yes & $\checkmark$ \\
\hline Parasite responsiveness to treatment & Excellent & Residual mf/ag-emia & No & \\
\hline Contiguous endemic areas & Under MDA treatment & Untreated & Yes & $\checkmark$ \\
\hline Sympatric Loa loa & No & Yes & No & \\
\hline Sympatric zoophilic Brugia & No & Yes & No & $\checkmark$ \\
\hline \multicolumn{5}{|l|}{ Economic/political/social } \\
\hline $\begin{array}{l}\text { Economic development of endemic } \\
\text { area }\end{array}$ & $\begin{array}{l}\text { High (including housing, } \\
\text { roads) }\end{array}$ & $\begin{array}{l}\text { Low, with poor physical } \\
\text { infrastructure }\end{array}$ & No & \\
\hline $\begin{array}{l}\text { Administrative development of } \\
\text { endemic area }\end{array}$ & High overall performance & Low performance record & No & \\
\hline Health system infrastructure & $\begin{array}{l}\text { Good (including local health } \\
\text { units) }\end{array}$ & $\begin{array}{l}\text { Poor, with weak national } \\
\text { MOH }\end{array}$ & No & \\
\hline $\begin{array}{l}\text { Urban population: socio-economic } \\
\text { status }\end{array}$ & $\begin{array}{l}\text { Lower (more difficult to reach, } \\
\text { easier to treat) }\end{array}$ & $\begin{array}{l}\text { Higher (easier to reach, } \\
\text { more difficult to treat) }\end{array}$ & No & $\checkmark$ \\
\hline Political stability, security & Good & Poor, high security risk & No & \\
\hline Political commitment for NPELF & Strong & Minimal & Yes & \\
\hline Compliance (people taking the drugs) & $\begin{array}{l}\text { High compliance rate; no } \\
\text { persistent non-compliance }\end{array}$ & $\begin{array}{l}\text { Persistent non-compliance } \\
\text { or poor compliance rate }\end{array}$ & Yes & $\checkmark$ \\
\hline Evident morbidity in population & $\begin{array}{l}\text { High (leads to perception of } \\
\text { importance) }\end{array}$ & $\begin{array}{l}\text { Low (inhibits recognition } \\
\text { of importance) }\end{array}$ & No & \\
\hline $\begin{array}{l}\text { Past experience of population with } \\
\text { LF or other MDA programs }\end{array}$ & $\begin{array}{l}\text { Good results, minimal } \\
\text { inconvenience }\end{array}$ & $\begin{array}{l}\text { Poor quality drugs, adverse } \\
\text { reactions }\end{array}$ & No & \\
\hline Migration from other endemic areas & Minimal & Extensive & No & $\checkmark$ \\
\hline
\end{tabular}


TABLE 2b

Factors affecting operational effectiveness of LF elimination programs

\begin{tabular}{|c|c|c|c|c|}
\hline Factor & Positive influence & Negative influence & $\begin{array}{l}\text { Readily } \\
\text { changeable }\end{array}$ & $\begin{array}{l}\text { Important/ } \\
\text { researchable }\end{array}$ \\
\hline Global program guidelines & Detailed, comprehensive & $\begin{array}{l}\text { Imprecisely defined goals, tools, } \\
\text { strategies (compliance, \# MDAs, } \\
\text { monitoring tools, sampling } \\
\text { strategies, stopping criteria) }\end{array}$ & Yes & \\
\hline Mapping of LF and other NTDs & Complete & Incomplete & Yes & \\
\hline Program management, leadership & Strong & Weak & Yes & \\
\hline Advocacy and fund-raising & Active and effective & Poor or non-existent & Yes & \\
\hline "Personpower" & Sufficient, well-trained, conscientious & Shortage, unskilled or untrained & Yes & \\
\hline Drug distributors & Well trained, well informed, compensated & Poorly motivated and trained & Yes & \\
\hline Social mobilization & $\begin{array}{l}\text { Strong (IEC/COMBI), with involvement of } \\
\text { village leaders }\end{array}$ & Inadequate & Yes & $\checkmark$ \\
\hline Drug quality & High and consistent & Uncertain or poor & Yes & \\
\hline Drug supply/delivery & Timely and coordinated for 2-drug delivery & Unreliable, uncoordinated & Yes & \\
\hline MDA organization & Well timed (dates, duration) & Shifting dates, conflicting dates & Yes & \\
\hline Drug administration & By Directly Observed Treatment & Not DOT & Yes & $\checkmark$ \\
\hline $\begin{array}{l}\text { Treatment "coverage" (tablets } \\
\text { distributed) }\end{array}$ & High (estimated $>70 \%$ total population) & Low & Yes & $\checkmark$ \\
\hline Treatment of "side reactions" & $\begin{array}{l}\text { Provision for rapid, effective management } \\
\text { (medical and "political") }\end{array}$ & $\begin{array}{l}\text { Inadequate response to person and } \\
\text { community needs }\end{array}$ & Yes & \\
\hline Morbidity management & $\begin{array}{l}\text { Strong program in place for lymphedema } \\
\text { management and hydrocoele surgery }\end{array}$ & $\begin{array}{l}\text { Minimal attention to morbidity } \\
\text { issues }\end{array}$ & Yes & \\
\hline Monitoring & $\begin{array}{l}\text { Independent, routine; following process } \\
\text { indicators, using good sampling strategies }\end{array}$ & $\begin{array}{l}\text { Insufficient frequency or attention } \\
\text { to detail }\end{array}$ & Yes & \\
\hline Evaluation & $\begin{array}{l}\text { Baseline mf- or ag-emia and reassessment } \\
\text { at defined intervals or potential program } \\
\text { end-point, using good sampling strategies }\end{array}$ & $\begin{array}{l}\text { No baseline values; poor sampling } \\
\text { strategy }\end{array}$ & Yes & $\checkmark$ \\
\hline $\begin{array}{l}\text { Adjunctive tools to } \\
\text { eliminate LF }\end{array}$ & $\begin{array}{l}\text { Vector control, twice-yearly MDA or } \\
\text { DEC-salt supplements in place }\end{array}$ & No adjunctive measures & Yes & $\checkmark$ \\
\hline $\begin{array}{l}\text { LF's relation to other NTD } \\
\text { Programs }\end{array}$ & Integration or strong coordination in place & $\begin{array}{l}\text { National program operates } \\
\text { independently }\end{array}$ & Yes & $\checkmark$ \\
\hline Community understanding & $\begin{array}{l}\text { Recognizes multiple benefits of MDA } \\
\text { (on LF, on intestinal parasites etc.) }\end{array}$ & $\begin{array}{l}\text { Inadequate information on } \\
\text { program's full benefits to } \\
\text { the population }\end{array}$ & Yes & $\checkmark$ \\
\hline Partnering organizations & Multiple and coordinated & Few or uncoordinated & Yes & \\
\hline Funding for LF program & Sufficient (best from national budget line) & $\begin{array}{l}\text { Inadequate, without ensured } \\
\text { continuity }\end{array}$ & Yes & \\
\hline $\begin{array}{l}\text { Link between national program } \\
\text { and research community }\end{array}$ & Good collaboration; shared responsibility & Competition, distrust & Yes & \\
\hline
\end{tabular}

previously as to require little or no further study, the effects of almost one-third of the identified determinants are poorly understood, and they require further study. Some reflect current uncertainties in the biology of the parasite and vector (including their interactions with each other and the human host); others reflect uncertainties about how best to design national programs to ensure success; and still others indicate uncertainties in the way people respond to MDAs.

"Biologic" research priorities. Two vector/parasite biologic issues, if more well defined, could have particular impact on program success: 1) quantifying the differences in vector competence (microfilaria uptake, L3 production) among the different vector species, particularly the anophelines in Africaas this would better define the "force of infection" that individual programs must confront and would affect decisions about the frequency and duration of MDAs required to interrupt LF transmission; 2) identifying potential seasonal variations of relevance to LF transmission (microfilaremia in humans, biting patterns in mosquitoes) in different endemic regions - as this might open opportunities to tailor the timing of MDAs to maximize their impact toward interrupting LF transmission.
"Programmatic" research priorities. A better quantitative understanding of the operational factors essential for program success would be particularly valuable for improving program outcome. Specifically, these factors would include: 1) the levels of population compliance required during MDAs to achieve interruption of transmission (and the levels of noncompliance or systematic non-compliance that still permit LF elimination);2) the levels of microfilaria (mf)-positivity or antigen-positivity at which the MDA component of programs can safely be stopped (i.e., an understanding of the "natural history" and programmatic implications of persistent antigenemia in mf-negative individuals and of low-level microfilaremia prevalence in communities after multiple rounds of MDA); 3) the number of rounds of MDA required for success in different epidemiologic situations-perhaps fewer in low endemicity areas and more, even with supplemental measures including vector control and enhanced drug regimens, in other epidemiologic settings.

Resolving programmatic uncertainties related to conduct of the MDAs themselves could also greatly increase the likelihood of individual program success. Particularly important are 1) defining the optimal drug distribution methods and strategies (Directly Observed Treatment [DOT] being the 
"gold standard") for use in different settings-including "problem settings" such as refugee, migrant, or urban areas; 2) determining the importance of interruptions in the planned yearly implementation of MDAs; 3) identifying the importance of conducting the MDAs in relation to transmission seasonality; and 4) understanding whether the effectiveness of MDA-based programs in Brugia endemic areas is affected by sympatric zoonotic Brugia infections.

"Community-focused" research priorities. The most important community-related uncertainty is the issue of compliance. It will be valuable to develop "compliance profiles" of communities to identify those groups of individuals who remain "persistently non-compliant" during MDAs (e.g., children, upper socioeconomic classes, young men, older ages), and then to determine the causes of this non-compliance and effective approaches to overcoming it.

\section{WAY FORWARD}

It is unlikely that studies will be carried out, or answers found, for all of these researchable questions in the near future. There are financial constraints, limitations in available study opportunities, and the fact that for some of these questions the essential research tools to address them are not yet in hand. However, because each issue is important and because answers to any can certainly lead to improvements in program design or execution, every opportunity to address them should be taken.

Program improvement, moreover, need not await the outcome of more research. The extensive programmatic experience summarized in Table 2 clearly identifies situations where specific steps can be taken immediately to improve the likelihood of success for LF elimination programs. Key determinants of successful outcomes have already been identified; the challenge for the Global Program now is to support national program managers in taking the right steps as quickly as possible.

Received June 16, 2008. Accepted for publication August 20, 2008.

Authors' addresses: Dominique Kyelem, Task Force for Child Survival and Development, 325 Swanton Way, Decatur, GA 30030, E-mail: dkyelem@taskforce.org. Gautam Biswas, World Health Organization, Avenue Appia 20, 1211 Geneva 27, Switzerland, Tel: +4122-791-21-11, Fax: +41-22-791-31-11, E-mail: biswasg@who.int. Moses J. Bockarie, Case Western Reserve University, Center for Global Health and Diseases, Wolstein Research Building Rm. 4129, 2103 Cornell Road, Cleveland, OH 44106, Tel: (216) 368-6285, Fax: (216) 368-4825, E-mail: mbockarie@gmail.com. Mark H. Bradley, GlaxoSmithKline, Global Community Partnerships, 980 Great West Road, Brentford, Middlesex TW8 9GS, United Kingdom, E-mail: mark.h.bradley@gsk.com. Maged El-Setouhy, Professor, Department of Community, Environmental and Occupational Medicine, Faculty of Medicine, Ain Shams University, Abbasia, Cairo, Egypt, Tel: +(202) 2685-3276, Fax: +(202) 2483-7888, E-mails: maged elsetouhy@yahoo.com and maged.elsetouhy@gmail.com. Peter U. Fischer, Washington University School of Medicine, Infectious Disease Division, Campus Mailbox 8051, 660 S. Euclid Ave., St. Louis, MO 63110, Tel: 314-454-7876, Fax: 314-454-5293; E-mail: PUfische@im.wustl.edu. Ralph H. Henderson, Task Force for Child Survival and Development, 325 Swanton Way, Decatur, GA 30030, E-mail: rafeh@bellsouth.net. James W. Kazura, Case Western Reserve University, Center for Global Health and Diseases, Wolstein Research Building Rm. 4129, 2103 Cornell Road, Cleveland, OH 44106, Tel: (216) 368-4810, Fax: (216) 368-4825, E-mail: james.kazura@case.edu. Patrick J. Lammie, U.S. Centers for Disease Control and Prevention, DPD/NCID/CCID, 4770 Buford Hwy NE,
MS F-13, Atlanta, GA 30342-3742, Tel: 001-770-488-4054, E-mail: pj11@cdc.gov. Sammy M. Njenga, Kenya Medical Research Institute, P.O. Box 54840, 00200 Nairobi, Kenya, Tel: +254-20-2722541, Fax: +254-20-2720030, E-mail: snjenga@kemri-nuitm.or.ke. Eric A. Ottesen, Task Force for Child Survival and Development, 325 Swanton Way, Decatur, GA 30030, E-mail: eottesen@taskforce.org. Kapa D. Ramaiah, VCRC, No: 12, Bhaktavatsalam Street, Tagore Nagar, Lawspet, Pondicherry—605 008, India, E-mail: ramaiahk@yahoo .com. Frank O. Richards, The Carter Center, One Copenhill, 453 Freedom Parkway, Atlanta, GA 30307, Tel: 404-420-5100, E-mail: fxr1@cdc.gov. Gary J. Weil, Washington University School of Medicine, Infectious Disease Division, Campus Mailbox 8051, 660 S. Euclid Ave., St. Louis, MO 63110, Tel: 314-454-7782, Fax: 314-454-5293, E-mail: GWEIL@im.wustl.edu. Steven A. Williams, Smith College, Clark Science Center, 44 College Lane, Northampton, MA 01063, Tel: 413-585-3857 ext. 3826, Fax: 413-585-3786, E-mail: swilliam@ email.smith.edu.

\section{REFERENCES}

1. Molyneux DH, Zagaria N, 2002. Lymphatic filariasis elimination: progress in global programme development. Ann Trop Med Parasitol 96: S15-S40.

2. Ottesen EA, Bradley M, Hooper PJ, Biswas G, 2008. The global programme to eliminate lymphatic filariasis: health impact after 8 Years. PLoS NTDS (in press).

3. Ramzy RM, El Setouhy M, Helmy H, Ahmed ES, Abd Elaziz KM, Farid HA, Shannon WD, Weil GJ, 2006. Effect of yearly mass drug administration with diethylcarbamazine and albendazole on bancroftian filariasis in Egypt: a comprehensive assessment. Lancet 367: 992-999.

4. El-Setouhy M, Abd Elaziz KM, Helmy H, Farid HA, Kamal HA, Ramzy RM, Shannon WD, Weil GJ, 2007. The effect of compliance on the impact of mass drug administration for elimination of lymphatic filariasis in Egypt. Am J Trop Med Hyg 77: 1069-1073.

5. De Rochars M, Direny A, Roberts J, Addiss D, Radday J, Beach M, Streit T, Dardith D, Lafontant J, Lammie P, 2004. Community-wide reduction in prevalence and intensity of intestinal helminths as a collateral benefit of lymphatic filariasis elimination programs. Am J Trop Med Hyg 71: 466-470.

6. Mathieu E, Direny AN, De Rochars MB, Streit TG, Addiss DG, Lammie PJ, 2006. Participation in three consecutive mass drug administrations in Leogane, Haiti. Trop Med Int Health 11: 862-868.

7. Grady CA, de Rochars MB, Direny AN, Orelus JN, Wendt J, Radday J, Mathieu E, Roberts JM, Streit TG, Addiss DG, Lammie PJ, 2007. Endpoints for lymphatic filariasis programs. Emerg Infect Dis 13: 608-610.

8. Ramaiah KD, Das PK, Vanamail P, Pani SP, 2003. The impact of six rounds of single-dose mass administration of diethylcarbamazine or ivermectin on the transmission of Wuchereria bancrofti by Culex quinquefasciatus and its implications for lymphatic filariasis elimination programmes. Trop Med Int Health 8: 1082-1092.

9. Ramaiah KD, Das PK, 2004. Mass drug administration to eliminate lymphatic filariasis in India. Trends Parasitol 20: 499-502.

10. Rajendran R, Sunish IP, Mani TR, Munirathinam A, Arunachalam N, Satyanarayana K, Dash AP, 2006. Community-based study to assess the efficacy of DEC plus ALB against DEC alone on bancroftian filarial infection in endemic areas in Tamil Nadu, south India. Trop Med Int Health 11: 851-861.

11. Vanamail P, Ramaiah KD, Subramanian S, Pani SP, Yuvaraj J, Das PK, 2005. Pattern of community compliance with spaced, single-dose, mass administrations of diethylcarbamazine or ivermectin, for the elimination of lymphatic filariasis from rural areas of southern India. Ann Trop Med Parasitol 99: 237242.

12. Ramaiah KD, Vanamail P, Das PK, 2007. Changes in Wuchereria bancrofti infection in a highly endemic community following 10 rounds of mass administration of diethylcarbamazine. Trans $R$ Soc Trop Med Hyg 101: 250-255.

13. Oqueka T, Supali T, Ismid IS, Purnomo, Rückert P, Bradley M, Fischer P, 2005. Impact of two rounds of mass drug adminis- 
tration using diethylcarbamazine combined with albendazole on the prevalence of Brugia timori and of intestinal helminths on Alor Island, Indonesia. Filaria J 4: 5.

14. Richards FO, Pam DD, Kal A, Gerlong GY, Onyeka J, Sambo Y, Danboyi J, Ibrahim B, Terranella A, Kumbak D, Dakul A, Lenhart A, Rakers L, Umaru J, Amadiegwu S, Withers PC, Mafuyai H, Jinadu MY, Miri ES, Eigege A, 2005. Significant decrease in the prevalence of Wuchereria bancrofti infection in anopheline mosquitoes following the addition of albendazole to annual, ivermectin-based, mass treatments in Nigeria. Ann Trop Med Parasitol 99: 155-164.

15. Bockarie MJ, Tisch DJ, Kastens W, Alexander ND, Dimber Z, Bockarie F, Ibam E, Alpers MP, Kazura JW, 2002. Mass treatment to eliminate filariasis in Papua New Guinea. $N$ Engl $J$ Med 347: 1841-1848.

16. Bockarie MJ, Kazura JW, 2003. Lymphatic filariasis in Papua New Guinea: prospects for elimination. Med Microbiol Immunol (Berl) 192: 9-14.

17. Tisch DJ, Bockarie MJ, Dimber Z, Kiniboro B, Tarongka N, Hazlett FE, Kastens W, Alpers MP, Kazura JW, 2008. Mass drug administration trail to eliminate lymphatic filariasis in Papua New Guinea: changes in microfilaremia, filarial antigen, and Bm14 antibody after cessation. Am J Trop Med Hyg 78: 289-293.

18. Wamae N, Njenga SM, Kisingu WM, Muthigani PW, Kiiru K, 2006. Community-directed treatment of lymphatic filariasis in Kenya and its role in the national programmes for elimination of lymphatic filariasis. Afr J Health Sci 13: 69-79.

19. Njenga SM, Wamae CN, Njomo DW, Mwandawiro CS, Molyneux DH, 2008. Impact of two rounds of mass treatment with diethylcarbamazine plus albendazole on Wuchereria bancrofti infection and the sensitivity of immunochromatographic test in Malindi, Kenya. Trans R Soc Trop Med Hyg [Epub ahead of print].

20. World Health Organization, 2004. Report on the mid-term assessment of microfilaraemia reduction in sentinel sites of 13 countries of the Global Programme to Eliminate Lymphatic Filariasis. Wkly Epidemiol Rec 40: 358-367.

21. World Health Organization, 2007. Global Programme to Eliminate Lymphatic Filariasis: progress report on mass drug administration in 2006. Wkly Epidemiol Rec 82: 361-380.

22. World Health Organization, 2008. Global Programme to Eliminate Lymphatic Filariasis: progress report on mass drug administration in 2007. Wkly Epidemiol Rec 83: 333-348. 